\title{
Malcolm H. Kerr
}

(1931-84)

Born in 1931 in Beirut, Lebanon, Malcolm Kerr was both a child and a student of the Middle East. His American parents had gone to Turkey in 1919 to work with the Near East Relief and eventually went to teach at the American University of Beirut. Malcolm was raised on the AUB campus on the terraced bluffs above the Mediterranean. His earliest memories of Lebanon were formed in the pre-World War II days of the French Mandate before the establishment of the state of Israel and the full flowering of pan-Arab nationalism. His family life and his education gave him a foot in two worlds and an abiding attachment and love of the Middle East.

The family spent the war years in Princeton, New Jersey, where Malcolm had his first taste of America. In his junior high school he was called "the boy from Syria" -an attribute he did not forget. When the war ended, the family went back to Beirut, and Malcolm returned to the American Community School for two years. Then in 1947, at not quite sixteen years of age, he left the Middle East to spend his last two years of secondary school at Deerfield Academy in western Massachusetts, a school where many sons of AUB families were sent to learn American values and institutions. He thrived on the rigorous academic and athletic programs and always said that Deerfield made a man of him. His quick maturation might also have been due to the fact that he had to spend most of one semester in the infirmary, incapacitated by early-onset arthritis. This affliction was with him all his life, but he learned how to live with it and keep it at bay much of the time.

Malcolm went on to Princeton where he studied international relations and specialized in the Middle East under Philip Hitti. His post-graduate plans to study at Oxford in 1953 were thwarted by a recurrence of arthritis; instead he returned to Beirut where he could live with his parents on the AUB campus and join the MA program in Middle East studies. During that time he met his future wife, Ann Zwicker, who was taking her junior year abroad at AUB from Occidental College in California. They were married in 1956, by which time Malcolm had started work on his PhD at Johns Hopkins School of Advanced International Studies. Choosing to write his thesis with Sir Hamilton Gibb at Harvard, the couple spent the next two years in Cambridge and had to find their way to the Johns Hopkins Baltimore campus where his graduation was held in 1958.

Two books resulted from his graduate studies. His master's thesis became Lebanon in the Last Years of Feudalism, 1840-1868: A Contemporary Account by Antun Dahir Al-Aqiqi. His PhD thesis became Islamic Reform: The Political and Legal Theories of Muhammad 'Abduh and Rashid Rida.

Malcolm's first teaching job was at AUB where he taught for three years in the Political Science Department. The first two of the couple's four children, Susan and John, were born during that time. From AUB, Malcolm was hired by Gustav von Grunebaum to teach at UCLA in the Center for Near Eastern Studies and the Department of Political Science. He delayed that appointment by a year to do post-doctoral study at St. Antony's College, Oxford with Albert Hourani. As with so many of Albert's students, the year of study together led to a life-long friendship.

Malcolm had a twenty-year teaching career at UCLA, but at every opportunity the family used leaves-of-absence and sabbaticals to get back to the Arab world. In 1964-65, Malcolm received a Social Science Research Council grant to Cairo where he completed his best known book, The Arab Cold War: Gamal Abd al-Nasir and His Rivals, 1958-1964, a study of the interplay of ideology and political tactics in Arab affairs and of Nasir's career as a pan-Arab leader. His concern was to dispel the notion of Arab politics as a projection of decisions made in Washington. The next year was spent teaching at AUB where the Kerr's third child, Stephen, was born. 
Shortly after his return to UCLA, he became chairperson of the Political Science Department, a job he declared in later years to be the best preparation for any kind of job in university administration. The Kerr's fourth child, Andrew, was born during that time, and a beautiful house on top of a mountain overlooking the Pacific was purchased before the inflation of real-estate prices began.

After the June War of 1967, Malcolm had become discouraged with Israeli-Arab politics, and so the family decided to spend time in France and North Africa during their next sabbatical in 1970-71. He obtained a grant to study the politics of higher education in North Africa. In actuality, he missed the issues of the eastern Mediterranean Arab world and neglected the politics of education in favor of working on the third edition of The Arab cold War. His concern for the problems of the region are revealed in the preface:

[S]ince June, 1967 Arab politics have ceased to be fun. In the good old days most Arabs refused to take themselves very seriously, and this made it easier to take a relaxed view of the few who possessed intimations of some immortal mission. It was like watching Princeton play Columbia in football on a muddy afternoon. The June War was like a disastrous game against Notre Dame which Princeton impulsively added to its schedule, leaving several players crippled for life and the others so embittered that they took to fighting viciously among themselves instead of scrimmaging happily as before. This may be instructive for the student of politics, but as one who all his life has had friendships and memories among the Arabs to cherish, I have found no relish in describing it.

Back at UCLA, the Kerrs spent a record five-year stretch in California, during which time Malcolm continued teaching and was appointed Divisional Dean of Social Sciences. He joined the ranks of 'air academics' who flew around to conferences giving papers, but, in the memories of his daughter and three sons, still managed to be a loving father who liked nothing better than to play basketball in the driveway or attend fatherdaughter Camp Fire Girl dinners.

In 1976-77, Malcolm was asked to be a visiting distinguished professor at the American University in Cairo. With civil war going on in Lebanon this was a good alternative to taking the family to AUB. During that sojourn, he obtained Ford Foundation support for a collaborative enterprise between the von Grunebaum Center and the Strategic Studies of Al-Ahram Foundation. This was to be a joint study by Egyptian and American scholars on the subject of rich and poor states in the Middle East. Returning to UCLA in 1977, Malcolm administered the program and became director of the von Grunebaum Center for Near Eastern Studies. Two years later the family again departed for Cairo where Malcolm ran the University of California Education Abroad Program and completed the rich and poor Arab states project with an edited book entitled, Rich and Poor States in the Middle East: Egypt and the New Arab Order. In the concluding chapter he wrote of five scenarios for the future of Egypt in the year 2000. Reading them today, they seem remarkably on target.

As much as the Kerr family loved Cairo, Malcolm's heart always belonged to Beirut and AUB. He had become a trustee of the university and traveled to Lebanon from Cairo during lulls in the Civil War. When he was asked to be the president of AUB in 1982, it seemed like an ideal job fit-except for the political climate-but it was easy to overlook the danger for the chance to lead the institution which stood for all the things he believed in and where his parents had taught for forty years. His enthusiasm for taking the job was summed up by his statement, "The only thing I'd rather do than watch Steve (his son who then played for the University of Arizona) play basketball is be president of AUB." The Civil War had been going on for seven years, but it was hoped that the shuttle diplomacy of Henry Kissenger that had brought about the exodus of the PLO 
to Tunis would soon bring peace. Betting on those chances and feeling a sense of calling to the job, the Kerrs decided to go to Beirut. Malcolm was president for only seventeen months. The war had not been spent but kept going for seven more years. On 18 January 1984, Maicolm was shot outside his office by two gunmen. Later Islamic Jihad made a telephone call to claim the credit for his death. The irony, of course, was that they had killed a man who understood and loved the Middle East as much as any foreigner could.

Malcolm's spirit is carried on in the American University of Beirut, where hundreds of students have studied under scholarships in his name, in the students he taught at UCLA, AUB, and AUC-and in his family. His children, in their own lives, personify and continue the various aspects of Malcolm's career and interests and reflect the values of their parents as they raise their own children.

There is probably no academic tribute that Malcolm would appreciate more than having the MESA dissertation award named after him. His own scholarship was forthright and honest to the point of sometimes getting him into trouble. While he was often thought of as 'pro-Arab' in writing about the Israeli-Arab conflict, he could be as critical of the Arabs as he was of the Israelis. He spoke the truth as he saw it and was committed to the cause of Arab-Israeli peace and to building understanding between the Arab World and the West. He was a founding member of MESA and served as president in 1972. Attending the fall meetings and seeing all his colleagues and friends was one of the highlights of his year. It is fitting that Malcolm Kerr's spirit and scholarly love of the Middle East are perpetuated in the MESA dissertation award.

ANN Z. KERR University of California, Los Angeles 